\title{
sciendo
}

\section{The Centre of Government as the CoOrdination Point FOR THE IMPLEMENTATION OF GENERAL LEGAL RULES}

\section{Mirko Pečarič ${ }^{1}$}

\begin{abstract}
This paper aims to establish a degree of existence of Hayek's idea of governmental assembly in the Centre of Government $(\mathrm{CoG})$, which is not only the technical, administrative support for the Prime Minister but has also a regulatory-coordinative, policy role. This paper's focus is on CoG that is along with the classical tasks of the Prime Minister's cabinet dedicated to systemic performance. Having this in mind a request was sent by the National Council of the Republic of Slovenia to other parliaments of the EU member states and Switzerland through the ECPRD net to gain information on the effectiveness of national CoGs and/or Prime Minister's cabinets vis-à-vis their systemic arrangement. Results show the presence of effectiveness, efficiency, economy, and ethics of legislation in countries, but they are not systemic in the eyes of system theory. Countries need to strengthen the inter-agency collaboration, systemic assessment of the effectiveness of general decisions in the real-time dimension, they need to check the relevancy of agency's reasons for a draft bill, there could be some performance indicators and possibilities to measure citizen satisfaction.
\end{abstract}

\section{Keywords}

The Centre of Government, Coordination, Legislation, Systemic Approach, Monitoring

\section{Introduction}

The legislation provides tangible benefits to a country and citizens by addressing public problems. For the well-targeted, evidence-based, flexible, responsive, easy to understand and comprehensively written legal rules that address the context and people in which and for which rules are enacted and implemented, there is a greater likelihood for the proper implementation, responsiveness and achievement of legal goals. Such rules are essential for the rule of law, the protection of common values, the effective functioning of public administration and the private sector. For qualitative legislation/regulation, it is assumed it is well-prepared, socially acceptable and effectively implemented in practice. Improving

\footnotetext{
${ }^{1}$ University of Ljubljana, Gosarjeva ulica 5, 1000 Ljubljana, Slovenia. E-mail: mirko.pecaric@ fu.uni-lj.si.
} 
a regulatory environment should be thus one of the permanent national priorities. On the other hand, numerous side effects of legislation put a shadow on the legislation's effectiveness and the above-given lines. People are many times captives of their ideas and usually blame anything but themselves for a present state of affairs. But when frames change also practices change, because 'character (êthos) is developed from habit (éthos)' (Aristotle, 1992). When a person wishes to improve society in general, he should try to change its frames, i.e. he 'should try to develop a capacity for legislating, if it is through laws that we will become good' (Aristotle, 2004). Aristotle also knew the good government does not exist if the laws, though well-established, are not obeyed. ${ }^{2}$ The good government thus exists when established laws are obeyed, and when these laws are well established (for even badly established laws can be obeyed) (Aristotle, 1998). Practical wisdom thus cannot be obtained only by learning general rules. It must be acquired and coordinated through the deliberative, emotional, and social skills that put our general understanding of well-being into practice. One solution to change ideas is to change frames in which the first emerge. Another well-known scholar who was interested in legislation and liberty is Hayek. He extended Aristotle's practical wisdom in the area of legislative science by dividing it into legislative and political science. His idea to prevent unlimited government is based on the separation of powers of representative assembly on two separate, independent, differently composed and democratically elected assemblies. An upper house, Legislative Assembly would represent an opinion of the people about which sorts of government actions are just, and the lower house or Governmental Assembly would be guided by a people's will on particular measures/interests of citizens as its electors. This house would be responsible for the routine affairs of government and should be taken within a frame of rules laid down by the upper house. ${ }^{3}$ Regulators should thus not only be attentive to regulatory frames but also how they are coordinated among different interests.

How should regulators, therefore, change regulatory frames within the uncertain and complex challenges whose scale and nature call for new approaches needed to solve wicked problems (i.e. problems characterized by uncertainty, complexity, exponentiality, divergent values, self-organisation, emergence, interdependent processes, structures and actors), how they could administrate them? Boundaries of knowledge limit a rational construction of the unchangeable and all-encompassing general rules focused in the future. This makes the rules of action, practice, adaptation and their institutional (re)organization all the more important along intensive endeavours to coordinate different actions towards common goals. Hume's "is-ought" problem (the impossibility to move from descriptive statements to prescriptive ones) (Hume, 2009) pushes decision-makers more and more towards the

\footnotetext{
${ }^{2}$ The same stands for Einstein: 'nothing is more destructive of respect for the government and the law of the land than passing laws which cannot be enforced' (Einstein, 2007).

${ }^{3}$ The different tasks require that the different assemblies should represent the views of the electors in different respects. For the government it seems desirable that citizens' wishes for particular results should find expression, or, in other words, that their particular interests should be represented; for the conduct of government a majority committed to a programme of action and "capable of governing" is thus clearly needed. Legislation proper, on the other hand, should not be governed by interests but by opinion, i.e. by views about what kind of action is right or wrong - not as an instrument for the achievement of particular ends but as a permanent rule and irrespective of the effect on particular individuals or groups (F. A. Hayek, 1998).
} 
trial and error method of problem-solving. Such problems call for constant adjustments throughout a policy cycle, with implications for how institutions, processes, skills and actors are organized. A possible answer to "how to adjust" is a systemic approach. Due to its focus on relations and outcomes, this approach requires multiple actors within and across levels of government to work together to avoid lesser responsiveness to political directions and weaker public accountability. Both mentioned consequences lead to the question: How organisations can respond as a whole to the political, economic and social changes in their environment? Although the Executive is in theory depicted as a unitary whole that takes care for the administration of laws, in practice ministers (according to their party discipline or to promote their successfulness) struggle for the biggest part of a national budget for their ministry. But as in all things, things are always connected to achieve unity. If there is an assumption of connectedness present, there is some higher-level that can recognize or establish such connections. Public administration processes are due to other relations, levels and their combinations - more effective when connected with some upper (governmental) level. Legitimacy can be established through coordination from a higher level, focused not only in the control of coercive powers, ${ }^{4}$ but in all state actions that have effects on a whole nation.

Even though Hayek's idea on that kind of Governmental Assembly did not come to life it could be present in the mentioned upper-level coordination; in this paper it is presented as the Centre of Government (CoG), is not only a technical, administrative support for the Prime Minister, but more and more has also a regulatory-coordinative, policy role. ${ }^{5}$ Due to such role it comes as a surprise the OECD report of 2014 Centre Stage is 'the first comprehensive effort to reflect on the central element of the public governance system and to better understand the role and potential of the Centre of government in supporting better policies' (Davies, 2014). CoG should at least, in theory, ensure executive decisions are coordinated and based on evidence. In Slovenia 0,014\% of the national budget of the Prime Minister's Cabinet coordinate other $99,98 \%$ of other governmental budget users. ${ }^{6}$ Due to more and more complex tasks, it is evident the Prime Minister's cabinet cannot fulfil this task with the classical way of doing things, mainly focused on the preparation of government sessions and its media activities.

\footnotetext{
${ }^{4}$ The Rule of Law implies limits to the scope of legislation: it restricts it to the kind of general rules known as formal law, and excludes legislation either directly aimed at particular people, or at enabling anybody to use the coercive power of the state for such discrimination. It means, not that everything is regulated by law, but, on the contrary, that the coercive power of the state can be used only in cases defined in advance by the law and in such a way that it can be foreseen how it will be used (Friedrich August Hayek, 2006).

${ }^{5}$ The term centre of government $(\mathrm{CoG})$ refers to the organisations and units that serve the Chief Executive (President or Prime Minister, and the Cabinet collectively) and perform certain crosscutting functions (strategic management, policy coordination, monitoring and improving performance, managing the politics of policies, and communications and accountability). The CoG includes a great variety of units across countries, such as General Secretariat, Cabinet Office, Office/Ministry of the Presidency, Council of Ministers Office, etc. (OECD, 2017b).

${ }^{6}$ CoGs represent a tiny fraction of total governmental expenditure - an average of $0.045 \%$ across OECD countries - and typically employ less than $0.1 \%$ of central government employment or fewer than 40 staff per million inhabitants (Davies, 2014).
} 
This paper thus differentiates between the Prime Minister's Cabinet and CoG, the latter seen as the Cabinet's systemic update in the complex environment. This paper's focus is on CoG that is along the classical tasks of the Prime Minister's cabinet dedicated to system performance, i.e. on the co-ordination of preparation and approval of the government's strategic priorities and work programme, co-ordination of the policy content of proposals for government decision making and monitoring of the government's performance to ensure the government collectively performs effectively and keeps its promises to the public. CoG as the higher institutional level should have not only the capacity to guarantee high-quality decision-making within a Bill, among Bills and valid law, but also to show high institutional coordination among ministries and other public agencies, along with a high devotion to the public values, political preferences, strategies and policy options. This means that scientific level should be added to the high personal stance towards the public interest.

\section{CoG as the Centre that Creates Situations}

According to American psychologist Zimbardo (2008) (known for the Stanford prison experiment), the banality of evil is equally as likely as the banality of heroism. Both occur in special situations where circumstances play the most important role for an individual, for his or her decision (not) to take measures or action. From a value-based view on any system management, one needs to realise there is 'greater power to make evil from good within the System [rather than in the behaviour of individuals] as a complex of powerful forces creating the Situation. Ample evidence from social psychology supports the concept that situational power prevails over individual power in the given circumstances' (Zimbardo, 2008). It thus matters how systems are arranged. A system documents information only if the latter's structure is similar to the system's structure. Some scholars intuitively considered this similarity in institutions, as the stable, valued, recurring patterns of behaviour (Huntington, 1968), as the persistent rules that shape, limit and channel human behaviour (Fukuyama, 2014) or decide what looks the same/different: '[s]imilarity is institution' (Douglas, 1986). Institutions decide what is similar, different, complex and chaotic. The law thus comes to life in institutions (Waldron, 2011). Creating situations that shape the System, these fragments of power, their mutual effects, influences and intertwining relate to systems that (do not) detect, recognise, examine and justify them. As power can be established in relationships (occurring not only in a single centre), it can be established through the various combinations of situations. It becomes clear the institutional possibility of checking data, information, arguments and the way of thinking can only be established with the effective coordination of these elements among different stakeholders within the same place and time.

Systems approach shifts the discussion from processes and organisational boundaries per se into a search for common grounds on how to achieve outcomes. The CoG can become a major actor for the articulation of government priorities and support of an outcomeoriented approach (OECD, 2017a). From their traditional role of serving the executive from an administrative perspective, COGs are now playing a more and more active role in policy development. CoG's can provide services that range from strategic planning to 
real-time policy advice and intelligence, and from leading major cross-departmental policy initiatives to monitoring progress and outcomes. These tasks are usually done without formal powers or competences and rests solely on the CoG's capacity to coordinate. The OECD identifies CoG's four priority tasks:

'supporting decision-making by the head of Government and/or Cabinet; policy coordination across government and leadership of cross-departmental priority strategies; monitoring progress with policy reform; and strategic planning, which is closely aligned with policy development and resource allocation [while] other highly valued functions on the centre include handling government communications and needs media strategy, managing relations with the legislature and preparing and operationalising the Government Programme' (Davies, 2014). ${ }^{7}$

$\mathrm{CoG}$ can be a new approach for the creation of situations and or circumstances in which public agencies are forced to cooperate not only to achieve their goals but primarily to achieve the common governmental goals. On a national level CoG can be described with the EU's motto "united in diversity", and understood as the system. The latter is effective when CoG's tasks are implemented effectively and efficiently. The real purpose/goal (of a system) is always implemented from behaviour/results, not from the stated goals. An increase in the number of regulations in Slovenia from 1991 to 2018 speaks for itself: $357 / 853$ statutes and 888/19694 by-laws (Tax-Fin-Lex, 2019) can (sometimes) be justified, but many of them had been enacted regardless of the previously mentioned governmental action plans. If we want to change modus operandi, it is not just about replacing parts, but about changing relations among them. The gist is to know that one or the other strategy "does not work", but to change a system's behaviour, its operations over time. If all (past) action plans and strategies were unsuccessful, the system does not work or it is not even present as the system (if new strategies are prepared in the same way, we can already conclude on their bad result). Responsive rules that match a context according to a rule's goal, the rules of responsibility that clearly define the responsibility of actors and tools that enable monitoring, and/or the gap between the written and enforced rules is necessary for a trustworthy legal system.

It is necessary to draw attention not only to the areas typically mentioned in documents (e.g. the insufficient institutional efficiency and performance characterized by lengthy administrative procedures, the inefficiency of public spending and governance, inadequate digitization, a high burden of regulations, a low level of participation and a high level of

\footnotetext{
${ }^{7}$ In the SIGMA paper, there are nine critical functions, to be implemented by the CoG, that are necessary for a well-organised, consistent and competent policy-making system. These are: co-ordination of preparation of the government sessions; ensuring legal conformity; co-ordination of preparation and approval of the government's strategic priorities and work programme; co-ordination of the policy content of proposals for government decision making, including defining the policy preparation process and ensuring coherence with government priorities; ensuring that policies are affordable and co-ordination of public sector resource planning; co-ordination of the government's communication activities to ensure a coherent government message; monitoring of the government's performance to ensure the government collectively performs effectively and keeps its promises to the public; handling relations between the government and other parts of the state (president, parliament); co-ordination of EI affairs (Vági, \& Kasemets, 2017).
} 
perception of corruption), but also to those that are not (the responsive, context-oriented rules, ways of collecting and processing data, systemic orientation and balance between objectives and tools/procedures for their implementation, learning how to prepare the rational general rules). A prerequisite for the good public service delivery is thus a good regulatory framework and its coordination. Since the internal consistency of theory can have a "hypnotic effect of satisfaction", its value must be tested in practice. Despite the value of uniform reporting, ${ }^{8}$ the Executive cannot be successful when focused (only) on the implementation of measures in sectors, without systemic governance of the whole regulatory framework.

\section{CoG as the Communication and Coordination Centre of Legislative Drafts}

At the executive level of government, the Prime Minister Cabinet is usually understood as the centre of government $(\mathrm{CoG})$ that ensures the basic functioning of the system. The role of $\mathrm{CoG}$ is not only to promote but also to implement evidence-based, strategic and consistent policies. The success of any government and the implementation of its key strategies and reforms depend on such Centre that achieves this general goal through the coordination of ministries and other public agencies. The overarching objective of the Centre is to ensure high-quality decision making by government and to align various government actions towards strategic goals. This can be done in numerous ways, while this paper is focused on the de facto horizontal/vertical coordination and management of public goals. The above-given lines in their words describe what has the OECD said for the case of Slovenia (OECD, 2012). Among other things the latter should:

* increase the use of business plans within ministries to clarify accountability and responsibilities for meeting government goals;

* develop mechanisms for consultation and agreement between the political level and senior civil service leadership, build leadership capacity, and establish accountability frameworks;

* establish a core Central Office ${ }^{9}$ to provide direct support and advice to the head of government and the Council of Ministers;

* define the institutions that make up the Centre of Government. Review and develop procedures and systems across the Centre of Government for more effective coordination;

* strengthen consultation and communication within and beyond the central administration. Improve legislative drafting and the application of regulatory impact assessment;

\footnotetext{
${ }^{8}$ A monitoring of governmental tasks is a particular challenge to provide the comprehensive, reliable and accurate picture of situations in different administrative areas and different agencies. Apart for a few similar bodies (e.g. administrative units), the various information and other more or less pragmatic solutions are generally used to monitor a solution of administrative matters, thus affecting the reliability, availability, completeness and quality of the data and, consequently, their basic usefulness for monitoring the functioning of the administrative system at the organizational and normative level and the system's adaptation to changed circumstances.

${ }^{9}$ The OECD's document Centre Stage (Davies, 2014) e.g. for Slovenia (contrary to our opinion) states the CoG exists - the Prime Minister's Office does not operate according to the above-stated four priority tasks.
} 
* consider a review of regulatory policy;

* develop a more appropriate balance of responsibilities between parliamentary legislation and executive orders;

* consider how to renew and refresh the social dialogue;

* develop and communicate a vision and clear roadmap for public sector reform;

* articulate reform priorities and define an action plan for their achievement;

* establish clear leadership responsibilities to push and guide reform.

A literature review revealed along with scant empirical evidence on the effects of different types of CoG configurations on the quality of policies, also a growing interest in the subject (Alessandro, Lafuente, \& Santiso, 2013). As the above-mentioned weaknesses could be present also in other countries the request was sent by the National Council of the Republic of Slovenia to other parliaments of the EU member states and Switzerland through the ECPRD (European Centre for Parliamentary Research and Documentation) net to gain information on the effectiveness of national $\mathrm{CoG}$ and/or Prime Minister's cabinet (if a country does not have $\mathrm{CoG}$ ) vis-à-vis the administration of general legal rules. The questionnaire was due to objectivity not sent to officials from $\mathrm{CoG}$, so the latter and/or tasks that are usually present in CoG were presented through the ECPRD respondents. The emphasis of the request was given not only on formal or normative descriptions but primarily on a factual state of affairs. Twelve states did not respond, while Latvia and Finland did not want to answer the questionnaire. They probably saw the latter as not relevant or do not see COG as the essential part of the systemic performance of legislation. Real reasons are unknown. The naming of "countries" could be too strong because they are here equated with the national ECPRD respondents, with their different knowledge, experience and skills. With this limitation in the following lines, the summary is made around the stated topics.

\section{Institution for the Supervision of Draft Documents}

The first question asked whether there is an institution (or a way of work) that supervises the draft bills, guidelines, strategies etc. are not contradictory between themselves, among other public institutions and to governmental goals (not only from a legal point of view but also from other social, economic, environmental etc. views). Countries' answers are divided into three groups: no central body, no central body but various processes and a central body.

\section{No central body}

There is no central body in France to examine bills and proposals both in terms of law and also in terms of their relevance to objectives set by the government. However, the Council of State has an advisory role in a legislative process. Under Article 39 of the Constitution, the Council is compulsorily included in the consultation of all bills (of governmental origin), before their adoption by the Council of Ministers and their filing in Parliament. The government is not obliged to follow the advice of the Council. Also, the consultation of the Council of State is optional in the case of legislative proposals (of parliamentary 
origin). Similarly, there is no such Centre in the Netherlands. Before each legislative Bill is discussed in Parliament it is sent to the Council of State for advice. In Spain, according to the provisions of the Government Act of 1997, the legislation is drafted by the competent Ministry. The draft should be annexed by the reports on the necessity and opportunity of the legislation and an economic report. The draft also requires a technical legal report of the General Technical Secretariat of the Ministry that ensures its constitutionality and legality. Eventually, other reports on legal and gender impact may be added. Once the draft bill is approved by the Council of Ministers, it is sent to the Congress of Deputies.

In Lithuania, there is no such single institution. According to the Statute of the Ministry of Justice the Ministry executes the following functions: formulates state policy in the areas of development of the national legal system and regulation of legal processes (including the legislative process), organises, coordinates and controls implementation of the aforementioned processes; prepares draft Government resolutions and other legal acts; issues conclusions on draft legal acts in cases and in accordance with the order prescribed by legal acts. The Government Office, under its Statute, verifies draft legal acts submitted to the Government and participates in improving the system of regulatory impact assessment. European Law Department under the Ministry of Justice coordinates the transposition of EU legislation into national law and its implementation and issues conclusions on the compliance of the draft laws and Government resolutions with the EU law. In practice, having started the way through the ministries, the draft law passes at least four filters - the initial evaluation of the project by the Ministry of Justice, review in the relevant ministries, evaluation by the Ministry of Justice in compliance with the Constitution, other laws and the EU law and finally in the Office of the Government. The Ministry of Justice is in charge of the coordination of monitoring of legal regulation. The Law on Legislative Framework establishes that monitoring shall be aimed at assessment of the impact of legal regulation both on the regulated area and other areas as well as their administrative burden. Execution of the assessment of administrative burden on economic operators constituted by applicable legal acts falls into the area of competence of the Ministry of Economy, where the administrative burden on citizens and other persons falls under the competence of the Ministry of the Interior. Thus, three Ministries are responsible for the coordination of the assessment of legal regulation.

In Turkey, there is no separate institution like the $\mathrm{CoG}$, but there are few units within the organization of the Presidency, which forms the executive branch, having similar functions attributed to CoG. These units are the Directorate of Administrative Affairs, with the Directorate of Law and Legislation and Directorates of Personnel and Principles and the Directorate of Security Affairs (the sub-units of the Directorate for Administrative Affairs), presidential policy boards, the Ministry of Justice and the Ministry of Treasury and Finance. In Estonia, according to Government of the Republic Act Estonia $\S 59$ (1), the Ministry of Justice coordinates legislative drafting. There is no special institution or agency that supervises that the draft bills, guidelines, strategies are not contradictory between themselves, among other public institutions and to governmental goals. The Rules of Procedure of the Ministries require that a regulatory impact assessment should always be carried out at the explanatory letter of a draft law, whenever legal norms (laws or 
general administrative regulations) are introduced, formulated and adopted. According to the Government rules and regulations (p. 5), an impact assessment shall be carried out based on the impact assessment methodology, which is approved by the Government.

\section{No central body, but various processes}

In Germany, there is no special institution or agency that supervises the draft bills, guidelines, strategies are not contradictory between themselves, among other public institutions and to governmental goals. However, in 2006 the Federal Government has established the so-called Standards Control Council (Normenkontrollrat - NKR). The NKR was instituted by law as an independent body to advise and support the Federal Government during the implementation of the government program. Moreover, the goal of the NKR is to measurably and verifiably reduce the cost of bureaucracy arising from existing information obligations. Moreover, the German Federal Government uses the instrument of long-term planning. Another instrument is the Regulatory Impact Assessment for draft laws which is legally anchored in $\S \S 43$ (1) No. 5, $\S 44$ of the Joint Rules of Procedure of the Federal Government.

In Austria, there is no such specific institution, but there are various processes that ensure such coordination. The Federal Chancellery and the Ministry of Finance are involved in most interdepartmental projects which aim at the preparation of basic strategies, legislation, documents etc. In particular, the Ministry of Finance has a very strong position and has to agree on all regulations, projects, etc. with financial implications. Besides, all draft laws should be subject to a comprehensive review procedure involving all the bodies concerned (but there are no formalised procedures). For all draft legislation and crossministerial strategies, a unanimous consensus in the council of ministers is necessary. Also, the organic budget law provides for outcome orientation as a basic budgetary principle and includes some quality assurance instruments for performance information in the budget and the accompanying materials to draft legislation (especially the outcome-oriented impact assessment). The Federal Performance Management Office (PMO) is responsible for the quality assurance of performance information in the budget documents concerning the high-level outcome objectives and measures (including performance indicators). The mandate comprises the assessment according to the following criteria: relevance, consistency, understandability, comparability, traceability and verifiability. Within this mandate also coordination of performance information between institutions should be carried out so that it is free of contradictions. The quality assurance includes also outcomeoriented impact assessment of draft legislative proposals and major projects.

\section{A central body}

In the UK, there is the Office of the Parliamentary Counsel (OPC). However, this deals only with the legal technicalities. There are many ways in which proposed legislation is scrutinised from a policy perspective. Ministers in the Department would have to approve it. Before a Bill is introduced into Parliament, it must be approved by the Business and Legislation Committee, (made up of certain ministers and chaired by the Leader of the House of Commons). As the Bill goes through Parliament, and amendments are proposed 
(whether by the Government or by backbench or Opposition MPs) the OPC continues to work with Government departments and also House of Commons officials in the Commons Public Bill Office and the House of Lords Public Bill Office. The Government draws up a programme of legislation for each session of Parliament. These are announced in the Queen's Speech on the occasion of the State Opening of Parliament. The list of Bills the Queen announces is not fixed, however. Other Bills may be introduced, and some Bills announced in the Speech may not in practice be introduced. The Cabinet Office is a Government Department which supports the Prime Minister and the Cabinet to deliver the Government's programme. Within the Cabinet Office, the Parliamentary Business and Legislation (PBL) Secretariat provides the secretariat for the Business and Legislation Committee, which is chaired by the Leader of the House of Commons and made up of 11 senior government ministers. The Committee's role is to "consider issues relating to the Government's parliamentary business and implementation of its legislative programme". There are also other central government organisations which are there to ensure that legislation does not interfere with wider government objectives. One example is the Better Regulation Executive within the Department for Business, Energy and Industrial Strategy; it works with government departments to ensure regulatory burdens on business are measured and reduced where possible. Government departments must produce impact assessments for all UK Government interventions of a regulatory nature that affect the private sector, civil society organisations and public services. These are made available with other Bill documentation to assist Parliament with the scrutiny of the legislation.

In Slovenia at the Governmental level there is the Office of legislation (OL) that ensures constitutionality and legality, the systemic coordination of legislation, and conformity with the legal drafting rules applying to laws and other state regulations, but this is usually done by one person that according to his knowledge supervises drafts are not contradictory with valid legal acts. Other aspects (except legal) are not considered, while coordination among other public institutions (with an institution that proposes new act) is done by content- or competence-involved institutions themselves, and not through OL. Legislative/regulative acts are usually not considered from strategic documents' points of view. Each year a Government normative program is made (what legal acts will be prepared and by which institution), but its effectiveness and efficiency are not considered. In Poland, there are three organisational entities at the governmental level: the Government Legislation Centre that cooperates with the Legislation Council and the Centre of the Strategic Research (responsible for the strategy of the key public policies). The Standing Council of Ministers' Committee is a subsidiary body whose task is to initiate, prepare and coordinate decisions and positions of the Council. Prime Minister nominates one of the members of the Council as a chairperson of the Committee. The Chancellery of the Prime Minister evaluates the cost-effectiveness of proposed regulations, their impact, prepares an evaluation of international conditionings of the country and long-distance foreign policy, as well as prepares other analyses, foresight, programs and evaluations commissioned by the Prime Minister. Legal opinions are issued by the Legislative Council, as to the constitutionality and the conformity with the legal system. The Government Legislation Centre is a body subordinate to the Prime Minister. The Centre provides coordination of 
activities of the Council of Ministers, the Prime Minister and of other government bodies. It prepares (similarly as the UK' OPC) government bills and other government acts, as well as positions of the Council of Ministers in legislative matters. It analyses judgements of the Constitutional Tribunal, judgements of other top national courts and the Court of Justice of the European Union as to their impact on the Polish legal system. The fulfilment of governmental goals as well as avoiding contradictions among draft bills are ensured through the duties of the members of the Council of Ministers. By a regular procedure draft bills should be agreed between the members of the Council of Ministers as well be a subject of obligatory consultations and opinions. An important part of the government legislative process is the impact assessment. There are teams for impact assessment within ministries. The Team for Programming the Workings of the Council of Ministers is responsible for checking on the impact assessment of the objectives of a bill at the stage of its inclusion in the register of the legislative plans of the Council of Ministers. Finally, the Department for Programming and Regulatory Impact Assessment of the Council of Ministers evaluates the quality of the impact assessment before a draft can be subject to agreement procedure, submitted to consultations or opinions. Recently the Center for Strategic Analyses has been organized. It encompasses four departments of the Council of Ministers' Chancellery: Department of Strategic Studies, Department of Regulatory Impact Assessment, Analyses Department and Department Analysing Defence Preparation of the Administration. The tasks of the Head of the Center include: developing program strategies in key policies, giving opinions regarding draft acts as to their impact and consistency with strategic goals, supporting Prime Minister with expert opinions, analysing Council of Minister's decisions in the context of strategic and program coherence.

In Greece, several institutions supervise the draft bills, guidelines, strategies and other documents are not contradictory. A competent authority is depended on the stage of the legislative procedure: the drafting of the bill, during the tabling of legislative proposals, and after. In general, Law 4048/2012 ("Regulatory Governance: Principles, Procedures and Means of Better Regulation") provides that the principles of good regulation are applicable in the preparation and evaluation of laws and regulations. Also, Ministers at the beginning of the regular session of the Parliament and as part of the Ministry's legislative planning, are obliged to inform the Office of Good Regulation on the number and scope of the bills they intend to introduce for approval in the Parliament. Means of better regulation are particularly consultation, impact analysis report, the explanatory statement of the law, the simplification, codification and reformation of law and the assessment of the implemented regulations. In the stage of drafting of a bill, the State Legal Council is competent for the legal drafting support, through its representatives in each Ministry. Additionally, according to Article 95 paragraph 1d) of the Constitution of Greece "the jurisdiction of the Supreme Administrative Court pertains to the elaboration of all decrees of a general regulatory nature". Social and economic aspects of a draft bill are assessed by the Economic and Social Committee. Its mission is to conduct social dialogue for the overall policy of the country and, especially, for the orientations of the economic and social policy, as well as to formulate opinions on Bills and law proposals referred to it, as required by article 82 paragraph 3 of the Constitution of Greece. Before tabling the draft bill to 
the Parliament, the General Secretariat of the Government processes the proposals of the Cabinet and makes sure they are not contradictory to the general goals of the government policy. Additionally, the Central Legislative Committee (part of the General Secretariat of the Government) is competent for the legislative elaboration of draft bills.

In Slovakia, the institution, that supervises and assesses draft bills before the Government's deliberations is the Legislative Council of the Government of the Slovak Republic (the Legislative Council) as the permanent advisory and coordinating body of the Government in the field of legislation. Furthermore, under the way of work that supervises draft bills, we can subsume the comment procedure (consultations), during which Ministries and public institutions can submit their objections and comments to the draft bills. In Romania, there are numerous central institutions at the disposal of the Government to support its work. They include, among others, a) the General Secretariat of the Government which role is to ensure the unfolding of technical operations related to government acts, the resolution of organizational, legal, economic and technical issues pertaining to the Government or the Prime Minister's activity, as well as the Government and the Prime Minister's legal representation; b) the Chancellery of the Prime Minister, which consists of a group of counsellors and experts; c) a special directorate; and d) the Prime Minister's cabinet. The ministerial secretary-general is the top-ranking public servant within the ministry and will act as its administrative head. One of the main reasons behind the creation of this post is the Government's intention to improve both intra-ministerial and inter-ministerial communication and coordination. Thus, the ministerial secretary-general acts as the chief link between ministerial line units and the political leadership of the ministry, including the minister, the state secretaries (deputy ministers) and their directors. Equally important, the secretaries-general constitute a network, with the Secretary-General of the Government at its centre. For example, weekly meetings of all ministerial general secretaries are envisaged, chaired by the Deputy Secretary-General of the Government. These meetings are expected, amongst other things, to play a key role in the preparation of the meetings of the Government. According to the Romania Constitution (art. 79), the Legislative Council shall be an advisory expert body of Parliament, that advises draft normative acts for a systematic unification and coordination of the whole body of laws. It shall keep the official record of the legislation of Romania. The Legislative Council is constituted as a specialized consultative body to Parliament, but it also fulfils an important role in the executive (i.e. pre-parliamentary) stages of legislation. Thus, all drafts of normative acts that are to be submitted to the Government must first be considered by the Legislative Council. Also, in the area of legislation, state aid and public-private partnership, the National Commission for Strategy and Prognosis participates in monitoring the implementation of the Governance Program, and performs analyses of the state of fulfilment of its provisions and proposes measures to achieve the objectives assumed under the Governance Program. It coordinates, together with the General Secretariat of the Government, the activity of public policy units in the ministries in terms of methodological and information and analysis work. 


\section{A Supervisory Institution and Real Outcomes}

The second question asked whether this institution is focused (only) that draft decisions are transformed in the legal forms or it is more concerned whether real outcomes are achieved. If the latter is relevant - are there any legal institutes (e.g. sunset clauses) or time frames when ex-post regulatory assessment should be done? In the UK, the OPC is concerned with the quality of legislation drafting rather than policy outcomes. Bills do sometimes have sunset clauses and statutory review provisions. These can be included in legislation on an ad hoc basis, where Parliament feels it should revisit the issue after a fixed period after the legislation comes into force. However, there is a special regime for new regulations (delegated legislation) affecting businesses. An independent Regulatory Policy Committee appointed by the Government assesses the impact on the business of new regulatory and deregulatory proposals. When a government department's policy change is going to impact business, then that department has to follow the Department for Business, Energy and Industrial Strategy's Better Regulation Framework Guidance. The procedure set out in this includes considering early on whether either sunset provision would be appropriate or whether a statutory five-yearly review clause is required by section 28 of the Small Business and Enterprise Act 2015. Parliament also does post-legislative scrutiny on certain Acts of Parliament independently of the Government. The function is performed by committees in the House of Commons and the House of Lords, with some oversight from the Commons Liaison Committee and the Lords Liaison Committee. However, only a small number of Acts are subject to formal scrutiny.

In Slovenia, the quality of drafting of legislation is a primary responsibility of OL, while the latter does not consider other goals. The latter is taken for a possible consideration only by MPs in legislative procedures. The majority of draft bills do not have any clauses based on time or other conditions that would invalidate act ipso facto when a condition is fulfilled. In Greece, the institutions stated above, focus on the legal formality of the law proposals (legislative elaboration) or the outcomes. The latter is specifically assessed at the Impact Assessment Report, which is an obligatory accompanying document for every draft bill. Besides, a relevant parliamentary control tool is provided in article 70 paragraph 6 of the Constitution of Greece: 'Parliamentary control shall be exercised by the Plenum, as specified by the Standing Orders. The Standing Orders may provide the exercise of parliamentary control also by the Section envisaged in article 71, as well as by the standing parliamentary committees established and functioning during the session'. More specifically, article 128B of the Standing Orders of the Hellenic Parliament states that: "During the exercise of legislative work in a standing committee, a discussion may be held, as specified in article 32, under MPs' initiative, regarding one or two issues of general importance or interest that fall within the competence of the Ministry that has tabled the relative bill or law proposal." Based on this provision, an ex-post form of control and regulatory assessment may be exercised.

In Slovakia, the Legislative Council is more concerned about how the draft bills are transformed in the legal forms. In Austria, the drafting of legislation including an impact assessment is a primary responsibility of line ministry. The PMO is responsible for the quality assurance of the ex-ante impact assessment of the draft laws and the coordination 
and the overall reporting on the ex-post impact assessment. The vast majority of draft bills do not have sunset clauses but ex-post internal impact assessments are required within 5 years of passing a new law or amendment. Results are reported to Parliament by the PMO. In Poland, the Government Legislation Centre and the Legislation Council concentrate on the compliance with the Polish law system (ex-ante) while the Centre of the Strategic Research is focused on the non-legal goals (ex-ante). Above that, the expost impact assessment can be prepared by one of the Ministers (which is in charge of the particular scope of the bill) among others on demand of the Council of Ministers or the Chief of the Centre of the Strategic Research. The Council of Ministers can prepare guidelines on the impact assessment.

In Romania, the Parliament, the Government and other authorities of the central and local public administration establish, in applying the norms of the legal technique provided in the law 24/2000 on normative technical norms for drafting normative acts, own regulations including the methodological, organizational measures, the deadlines and the circulation of draft normative acts within their sphere of competence. The primary responsibility for ensuring the timely implementation of Government decisions lies with the individual ministries. Also, the Directorate for Evidence maintains a computerized information system designed to monitor the implementation of Government decisions. Where the ministries fail to provide status reports on time or to implement decisions within the deadlines set by the Government, the Directorate for Evidence will pursue the matter.

In Lithuania, institutions are focused only that draft decisions are transformed in the legal forms; they are not focused on whether real outcomes are achieved. The National Audit Office (Supreme Audit Institution), in its Public Audit Report of 2018, assessed whether the applicable legislative process ensures the creation of the unified, coherent, sustainable and effective legal system. It was concluded in the Report that participants of the legislative process do not properly fulfil their duties requiring impact assessment of the envisaged legal regulation. Customarily preparation of draft legal acts does not include the impact assessment of envisaged legal regulation or this assessment is merely a formality. The estimates made are unreasonable and unjustified, possible alternatives to legal regulation are not provided. Legal acts define areas and cases to be subject to impact assessment of envisaged legal regulation however, no effective system still exists for assessing and monitoring of the impact assessment process. 9 Ministries out of 14 do not record processes carried out during the preparation of the draft legal act and assessment of its potential effect. To ensure the consistent and focussed improvement of the existing legal regulation, as well as efficient use of human resources The National Audit Office, recommended to reorganising the legal regulation monitoring system in a way, concentrating all competencies of various institutions required for proper assessment of legal regulation.

In Estonia, interest groups are engaged in the ex-post impact assessment of an Act following the Good Practice of Involvement. If the implementation of an Act presumably causes significant impact, an impact assessment will be appended to the explanatory memorandum. An impact assessment sets out the obligation to submit an ex-post impact assessment, the activity plan for the preparation thereof, including the estimated date for 
the performance thereof, the main types of impact and assessment criteria, or justifies the lack of necessity to carry out an ex-post assessment. In Poland, some of the abovementioned institutions are focused on the real outcomes, other - on the legal forms. There are no sunset regulations. In Romania, according to the law (24/2000), the draft normative act must establish the necessary, sufficient and possible rules that lead to as much stability and legislative efficiency. The solutions it contains must be thoroughly substantiated considering the social interest, the legislative policy of the Romanian state and the requirements of the correlation with the internal regulations as well as the harmonization of the national legislation with the community legislation and with the international treaties to which Romania is a party. The preliminary assessment of the impact of the draft laws, legislative proposals and other draft normative acts represents a set of activities and procedures carried out to ensure an adequate substantiation of the legislative initiatives. The preliminary impact assessment involves identifying and analysing the economic, social, environmental, legislative and budgetary impacts produced by the proposed regulations. The preliminary impact assessment is carried out by the initiator of the draft normative act. In the case of complex draft regulatory acts, the impact assessment may be carried out based on a service contract by scientific research institutes, universities, commercial companies or non-governmental organizations under the legal provisions in force concerning public procurement.

\section{Supervisory Institution and Overall Governmental Goals}

The third question asked whether this institution is focused on how the goals and objectives of Ministries contribute to overall government priority goals. In Slovenia, the OL does not do this. This is the Prime Minister's responsibility. In the UK the OPC is not focused on how individual ministries contribute to overall government priorities. As in Slovenia, this is ultimately a matter for the Prime Minister, as are the mechanisms through which she does this. The Cabinet Office plays an important role in setting standards and producing guidance for government departments - for example, Single Departmental Plans, spend controls and guidance on consultations. In addition to the OPL, there are other groups of staff based in the Cabinet Office and at the Prime Minister's Office, which support the Prime Minister in coordinating government policy (e.g. the Implementation Unit is responsible for tracking progress on government priorities). In Greece, this issue is handled during the regular meetings of the Cabinet, where all ministerial activities are reported. Also, the General Secretariat of the Government deals with matters regarding the general legal policy of the government and coordinates the overall government priority goals and policies. In Slovakia, the Legislative Council does not explicitly focus on how the goals and objective of Ministries contribute to overall goals. This falls to the responsibility of each Ministry. The Legislative Council only discusses the draft legislative plan of the Government, which is usually drafted for a while and coordinates and directs the activities of the ministries and other central state administration bodies in the preparation of draft laws and drafts of government regulations. 
In Austria, the PMO's mandate focuses on a formal quality according to the following criteria: relevance, consistency, understandability, comparability, traceability and verifiability. It is not focused on a material assessment of the objectives that are under the responsibility of the line ministries and coordinated within the council of ministers. In Poland, the compliance of the goals and objectives of Ministries with the government priority goals is the Prime Minister's responsibility and one of the tasks of the Center for Strategic Analyses. In Romania, the National Commission for Strategy and Prognosis elaborates forecasts regarding the economic and social development of Romania in the short, medium and long term, in correlation with the provisions of the Government Program, of the national, sectoral and regional strategies, as well as on the trends in the national and world economy. The Commission fundaments Romania's strategic economic and social development guidelines, in correlation with the provisions of the Government Program and the national, sectoral and regional strategies, highlighting the strategic priorities for achieving the undertaken development objectives. It elaborates annually or whenever necessary reports on the implementation of the measures of the Government Program, which it proposes for analysis to the Economic Programming Council and submits them to the Prime Minister. It also develops econometric models and methods for assessing the effects of structural reforms and public policies, such as general and structural equilibrium models. In Lithuania, there is no formal institution that would be focused on overall government priority goals. In Estonia, the State Chancellery has been responsible for coordinating the implementation of the strategic development plans of sustainable development.

\section{Interagency Collaboration}

The fourth question asked whether there is any kind of interagency collaboration to achieve the agency's goals and objectives. In Slovenia, based on the Resolution on Legislative Regulation (a resolution is not a legal act, but a political) Ministries must monitor and regulate areas for which they were established. The Rules of Procedure of the Government of the Republic of Slovenia demand that before submitting to the Government, government documents must be coordinated with the ministries and government departments concerned for inter-ministerial consideration. Individual ministries and government departments must, at all stages of the preparation and treatment of government documents, monitor the adequacy of that part of the assurances and solutions from the proposal of the materials falling within their jurisdiction. Proposals for general acts and acts of the government's business must be previously coordinated with the ministry responsible for finance and the government service responsible for legislation, which gives a written opinion on (legal) compliance. The proposer of the legislation/regulation invites experts and other public to participate in the preparation of the general rules with a general invitation, which is attached to the draft regulation, on the web pages. The proposer of the regulation may also expose individual questions addressed to a concrete organization, a civil society person or an individual expert utilizing an invitation to participate, to which the draft regulation is attached. The proposer of the regulation shall inform the expert or other public referred to in writing about the essential 
proposals or opinions that have not been considered, explaining the reasons within 15 days of the adoption of the regulation or the forwarding of the proposal to the next procedure. The public is not invited to participate in the preparation of the draft state budget, draft budget to rebalance, draft amendments to the state budget, draft law on the implementation of the state budget and the implementing regulations on the basis thereof. Formally this field is arranged, but in practice is not considered as it should be.

In Greece, the inter-ministerial collaboration secures the achievement of goals and objectives during the regular meetings of the Cabinet, where ministerial activities are discussed. To secure the legal formality and the substantive accuracy of the proposal, an ad hoc system of inter-ministerial coordination has been established. Additionally, ministries proposing a bill reach out to the institutions stated above under the first question to ensure the best possible outcome of their initiative. In Slovakia, a draft bill is discussed with competent authorities and institutions during comment procedure. In Austria, when preparing the performance information for the budget the PMO coordinates between the different line ministries with overlapping activities but has no direct possibility of intervention. Line ministries have to explain if they do not accept proposals of the PMO. In their strategic and operational activities, line ministries cooperate in overlapping areas but the ways of cooperation depend on the policy field and can be more or less formal. In Poland, according to the $\S 3$ of the Standing Orders of the Council of Ministers, '[b]efore a case is submitted for consideration by the Council of Ministers, a member of the Council of Ministers agrees on a standpoint with other members of the Council of Ministers'. According to the above-mentioned act, specific provisions may oblige to agree on a standpoint with other entities, if the draft concerns their scope of competence. The other entity must be given at least 14 days to prepare a written opinion. A proposer of a bill invites the public to the public consultations on the web pages. The proposer may also expose individual questions addressed to a concrete organization, a civil society person or another entity. The Council of Ministers can prepare guidelines on the public consultations. The proposer is obliged to prepare a consultation report in which the results are explained.

In Romania, a ministry proposing a normative act has the primary responsibility for ensuring proper consultation with other relevant ministries and central offices. Ministries to be routinely consulted include the Ministry of Justice, which must confirm the legality of all draft normative acts; the Ministry of Finance, to which all proposals with financial implications must be submitted; and the Council for Reform, which has to be consulted on all matters that relate to the restructuring of the economy and institutional reform. The Legal Department of the Government, through the Legal Service: follows, in the case of each draft normative document sent to the General Secretariat of the Government to include on the Government's agenda, the observance of the provisions of the Regulation on Procedures, at the Government level, for the elaboration, approval and presentation of draft public policy documents, drafts of normative acts, as well as other documents, for adoption / approval, approved by the Government Decision no. 561/2009. In this regard, it verifies the fulfilment of the formal requirements, the observance of the normative technical norms and, if necessary, draw up a note containing proposals and/or observations; verify 
the existence of the supporting note (in the case of comments with observations), as well as the comparative table and the concordance table, as appropriate. The Legislative Council is asked to assess, inter alia, whether the proposal meets formal requirements; is in line with the Government's legislative program, and is compatible with existing law. The Legislative Council is a specialized consultative body to Parliament, but it also fulfils an important role in the executive (pre-parliamentary) stages of legislation. Thus, all drafts of normative acts that are to be submitted to the Government must first be considered by the Legislative Council. It is, inter alia, required to remark on the legality of the proposed measures; their internal consistency; their adherence to accepted standards of legislative technique; and their impact on existing legislation and the legal system as a whole. Consultation of the Legislative Council is mandatory; however, it acts in an advisory capacity, and its opinions are not binding on the Government. The deadlines within which the Legislative Council has to submit its opinions are tight.

In Estonia, ministries must monitor and regulate areas for which they were established. The ministries must get approval for draft legislation or other matters to the Government of the Republic by other ministries and the State Chancellery. Sufficient time must be given to coordinate a bill or other matter that is necessary for a substantive examination of the matter. The draft law or other matter shall be approved or reasonably not approved within fifteen working days, generally within twenty working days of the Ministry of Justice. In justified cases, the deadline may be changed by the submitter or at the request of the coordinator for approval. EU affairs are generally coordinated within three working days and the deadline for the approval of the draft Ministerial Decree is generally ten working days.

\section{A Real-Time Dimension of the Effectiveness of General Decisions}

The fifth question asked whether this institution can systematically asses in the real-time dimension the effectiveness of general decisions. In Slovenia, the OL does not have an evaluation system, neither laws do not have criteria that would allow an assessment of their impact in real-time dimension. In the UK, the OPC does not have this role. In Greece, Article 98 of the Constitution provides that, the Court of Audit is competent of monitoring in real-time dimension. Furthermore, Independent Authorities, like the Ombudsman, can exercise real-time control of the effectiveness of the Executive's policy decisions that are formulated in the laws. In Slovakia, the Legislative Council does not have this function. A draft bill is submitted with a specific intent - a submitting ministry should, therefore, asses the effectiveness of its decisions. Furthermore, this also falls under the scope of the Parliament, which exercises its power of scrutiny primarily towards the Slovak Government and its members. In Austria, performance reporting that concerns performance information in the budget is done once a year and the ex-post internal impact assessments of new legislation and major projects are collected by the PMO and also reported once a year to Parliament and the public. In Poland, Romania and Estonia legal acts do not have criteria that would allow an assessment of their impact in real-time dimension. 


\section{A Relevancy of Agency's Reasons in Draft Bills}

The sixth question asked how this institution checks the relevancy of an agency's reasons for a draft bill/general decisions/strategy. In Slovenia, the OL assesses reasons mainly through the prism of constitutionality and legality. Logic, system's view, statistics, economy and other tools of evidence-based decision-making are usually not done. Similar is in Poland (the Government Legislation Centre and the Legislation Council assess reasons through the principle of legality. The Centre of the Strategic Research evaluates the reasons through the prism of the strategic goals of the Council of Ministers), and Estonia (the Ministry of Justice assesses reasons mainly through the prism of constitutionality and legality). In the UK, this is not the OPC's role. The Cabinet Office's Guide to making legislation sets out requirements for government departments to publish Explanatory Notes and Impact Assessments and other compulsory publications to explain reasons for legislation.

In Greece, the relevancy of reasons for a draft bill is secured by the explanatory report, which is checked during the ordinary legislative procedure of the Parliament by the competent standing parliamentary committee or the Plenum. Specifically, article 74 paragraph 1 of the Constitution provides that "every Bill or law proposal must be accompanied by an explanatory report". Furthermore, under the provision of article 85 paragraph 3 of the Standing Orders 'it is mandatory that bills and law proposals be accompanied by an explanatory report which must contain the reasons and the aims of the proposed provisions, as well as the entire text of those provisions that according to the bill or the law proposal are amended'. In Austria, the mandate of the PMO comprises the assessment of draft bills according to the following criteria: relevance, consistency, understandability, comparability, traceability and verifiability. General decisions or strategies which are not decided in the form of legislation, are not subject to this process. In Romania, the draft legislation initiated by the competent authorities must be accompanied by the presentation and motivation tools endorsed by public institutions and interested bodies. The preliminary impact assessment involves identifying and analysing the economic, social, environmental, legislative and budgetary impacts produced by the proposed regulations. The preliminary assessment of the impact of draft normative acts is considered to be the basis for the proposed legislative solutions and must be done before the adoption of the normative acts. The foundation of the new regulation should consider both the impact assessment of the specific legislation in force at the moment of drafting the normative act, as well as the assessment of the impact of the public policies that the draft normative act implements. The Government Training Meetings Directorate fulfils the following attributions, through the Government Preparatory Service meetings verifies the fulfilment of the formal conditions by the draft normative acts, including observance of the normative technical norms provided by the Law no. 24/2000, republished and requests the written opinion of the Legislative Council in the case of draft normative acts. The National Commission for Strategy and Prognosis develops specific methodologies and models for assessing the ex-ante and ex-post impact and economic programming. 


\section{Performance Indicators}

The seventh question asked whether there are performance indicators or some other ways through which general decisions' effectiveness can be (objectively) measured. In Slovenia, there are no such indicators. In the UK, the Government uses Single Departmental Plans to measure the performance of government departments, and there are other mechanisms as well. In Greece, there are such indicators. With the legal provisions of article 5 of Law 3230/2004 the framework of monitoring the implementation of the objectives of public authorities has been established, using indicators measuring performance and effectiveness. Slovakia and Poland do not have such indicators. In Austria, both the outcome and output indicators (and where relevant also disaggregated by gender) are present. For all objectives in the performance budget indicators have to be used to measure success. In Romania, with the legal provisions of the Decision No. 1.807 of 13 December 2006 for the approval of the Management Component of the Methodology on the Medium-Term Strategic Planning System of the Public Administration Institutions at Central Level, the framework of monitoring the implementation of the objectives of public authorities has been established, using indicators measuring performance and effectiveness. All ministries have the obligation to develop strategies for three-year periods as a consequence of the above-mentioned legislation.

\section{Monitoring of Citizen Satisfaction with Public Services and Institutions}

The eight-question asked whether regular monitoring of citizen satisfaction with public services and institutions is enabled on a governmental or an agency's level. In Slovenia and Estonia, there is no such regular monitoring that would compare the accomplishment of legal goals vis-à-vis citizen satisfaction. In the UK, the Government requires government departments to measure public satisfaction with their digital services. Other services overseen by government departments may be provided by many organisations, and they are scrutinised in many ways. Sometimes these will involve systematic monitoring of user satisfaction (e.g. the National Health Service Patient Services in England) but not all of them. In Slovakia and Poland, there is no such regular monitoring. The same stands for Romania, where the General Secretariat of the Government, through the Public Relations Department (DRP) has a task to provide public information and have a relationship with citizens. Also, the Romanian Ombudsman is an independent institution of the Government of Romania, responsible for investigating and addressing complaints made by citizens against other government institutions. In Greece, monitoring is present through the Greek Ombudsman introduced by article 103 paragraph 3 of the Constitution: "A law defines the issues pertinent to the formation and the jurisdictions of the Greek Ombudsman, which functions as an independent authority". Its mission is to safeguard and promote children's rights, to promote equal treatment and fight discrimination in the public sector based on race, ethnicity, religious or other conviction, disability, age or sexual orientation to monitor and promote the application of equal opportunities and equal treatment of men and women. As a mediator, the Greek Ombudsman makes recommendations and proposals to the public administration. The Ombudsman does not impose sanctions or annul illegal 
actions by the public administration. Also, the General Inspector of Public Administration is the Independent Authority that according to its mission promotes the values of legality, integrity, transparency and accountability in Greek Public Administration. The mission of the General Inspector of Public Administration is to ensure the efficient and effective functioning of public administration, to monitor the action and evaluate the performance of all the Inspecting-Controlling Bodies/Units of Public Administration and to detect and struck down corruption and maladministration phenomena. In Austria, there is no regular monitoring but some ministries, however, conduct citizen satisfaction analysis and include them in the performance information.

\section{Description of Draft Rules}

The ninth question has been focused on draft rules and their description. In Greece, every draft law must be accompanied by specific reports. In Austria, the impact assessment includes an explanation of the rationale of the reform, performance indicators and a financial estimate. All draft legislation is subject to a consultation process that involves stakeholders but also all citizens that like to comment on the draft before the final proposal is submitted to Parliament. Questions like i) how strategies and resources required to achieve the agency's goals and objectives are used in draft laws, ii) how the agency's goals and objectives incorporate input from the parliamentarian, interest organisations' or citizens' consultations, iii) how the agency's performance goals and priority goals relate to its general goals and objectives, iv) how external factors that could significantly affect the achievement of the agency's goals and objectives and v) how time and content (criteriabased) evaluations used to establish or review the agency's general goals and objectives, are unanswered in other countries.

\section{Preliminary Conclusions}

The 2014 OECD Survey on the Organization and Functions of the Center of Government found the vast majority of countries have a recognizable $\mathrm{CoG}, 90 \% / 60 \%$ of countries identified decision-making support/policy coordination as the two of top tasks of CoG. The 2015 OECD Delivering Priority Strategies document found 'the centre [CoG] is now a key vehicle for driving policy priorities [because] the Centre of government's role is necessary for ensuring that high quality, evidence-based, reviewed, and verified information is gathered and presented in a format that clearly defines the different options and their implications' (OECD, 2015). The 2017 OECD Survey based on 35 responses of Senior Officials from $\mathrm{CoG}$ concluded that in 23 responding countries $\mathrm{CoG}$ is leading the implementation of the sustainable development goals either on its own or with one or several line ministries (OECD, 2017b). These rather promising results on CoG cannot be confirmed from our questions.

No special bodies - there are no bodies in Greece (responsibility for various elements rests with the Ministry of Interior and Administrative Reconstruction, the General Secretariat to the Government through the Better Regulation Office, the Ministry of Finance or with individual ministries; the BRO co-ordinates regulatory policy across all administrations), 
Spain, France (the legislation is drafted by the competent Ministry), Lithuania, Estonia (in both countries the Competent ministry and the Ministry of Justice), Romania (legislation is drafted by the competent Ministry, while the Legislative Council is an advisory expert body of Parliament that also fulfils an important role in the executive - all drafts of normative acts that are to be submitted to the Government must first be considered by the Legislative Council) and Turkey (there is Directorate of Administrative Affairs with its subunits that help the President).

A special body (but not in a manner of CoG) - it exists in Greece (the Central Legislative Committee), Slovenia (the Legislative Council), Slovakia (the Legislative Council), Poland (the Government Legislation Centre; it cooperates with the Legislation Council and the Centre of the Strategic Research, while the fulfilment of governmental goals as well as avoiding contradictions among draft bills are ensured through the duties of the members of the Council of Ministers), Romania (the Legal Department of the Government), the UK (the Office of the Parliamentary Counsel), Austria (the Federal Performance Management Office is responsible for the quality assurance of performance information in the budget documents concerning the high-level outcome objectives and measures (including performance indicators) and Germany (the Standards Control Council).

Impact assessment and real outcomes - in Poland, the Chancellery of the Prime Minister evaluates the cost-effectiveness of proposed regulations, their impact, prepares an evaluation of international conditionings of the country and long-distance foreign policy, as well as prepares other analyses, foresight, programs and evaluations commissioned by the Prime Minister. There are teams for impact assessment also within ministries. The Government Legislation Centre and the Legislation Council concentrate on compliance with the Polish law system (ex-ante) while the Centre of the Strategic Research is focused on the non-legal goals (ex-ante). There are no sunset clauses. In the UK, the OPC is concerned with the quality of legislation drafting rather than policy outcomes. Bills do sometimes have sunset clauses and statutory review provisions. In Slovenia, Slovakia and Lithuania the quality of drafting of legislation is a primary responsibility of the Legislative Council, while it does not deal with the achievement of real outcomes. A competent ministry in Slovenia and Slovakia must prepare the impact assessment report, which is - as in Greece and Austria - an obligatory accompanying document for every draft bill. In Lithuania, the usual preparation of draft legal acts does not include the impact assessment of envisaged legal regulation or this assessment is merely a formality (the latter many times stands also for Slovenia). Nine out of fourteen ministries do not record processes carried out during the preparation of the draft legal act and assessment of its potential effect. To ensure the consistent and focussed improvement of the existing legal regulation, as well as efficient use of human resources The National Audit Office, recommended reorganising the legal regulation monitoring system in a way, concentrating all competencies of various institutions required for proper assessment of legal regulation. In Austria, the PMO is responsible for the quality assurance of the ex-ante impact assessment of the draft laws and the coordination and the overall reporting on the ex-post impact assessment. The vast majority of draft bills do not have sunset clauses but ex-post internal impact assessments are required within 5 years of passing a new law or amendment. The preliminary impact 
assessment in Romania is carried out by the initiator of the draft normative act. In the case of complex draft regulatory acts, the impact assessment may be carried out based on a service contract by scientific research institutes, universities, commercial companies or non-governmental organizations under the legal provisions in force concerning public procurement. The National Commission for Strategy and Prognosis also develops specific methodologies and models for assessing the ex-ante and ex-post impact and economic programming.

Overall government priority goals - in Slovenia the OL does not do this. This is the Prime Minister's i.e. its Cabinet Office responsibility (the same stands for the UK, Greece, Slovakia, Austria, Poland, Estonia). Interagency collaboration - in Slovenia, based on the Resolution on Legislative Regulation (a resolution is not a legal act, but a political) Ministries must monitor and regulate areas for which they were established. The Rules of Procedure of the Government of the Republic of Slovenia demand that before submitting to the Government, government documents must be coordinated with the ministries and government departments concerned for inter-ministerial consideration. Proposals for general acts and acts of the government's business must always be previously coordinated with the ministry responsible for finance and the government service responsible for legislation, which gives a written opinion on compliance. Similarly stands for the UK, Poland, Estonia and Romania. In Greece, the inter-ministerial collaboration secures the achievement of goals and objectives during the regular meetings of the Cabinet. In Austria, when preparing the performance information for the budget the PMO coordinates between the different line ministries with overlapping activities but has no direct possibility of intervention.

Systemic assessment of the effectiveness of general decisions in the real-time dimension - the Romanian Directorate for Evidence maintains a computerized information system designed to monitor the implementation of Government decisions. In Slovenia, the OL does not have an evaluation system, neither laws do not have criteria that would allow an assessment of their impact in real-time dimension. In the UK, the OPC does not have this role. Similar is for Slovakia. Greece gives a role here to the Court of Audit and the Ombudsman. In Austria, performance reporting that concerns performance information in the budget is done once a year and the ex-post internal impact assessments of new legislation and major projects are collected by the PMO and also reported once a year to Parliament and the public. In Poland, Romania and Estonia legal acts do not have criteria that would allow an assessment of their impact in real-time dimension. Checks on the relevancy of agency's reasons for a draft bill - there are no such checks in the abovementioned countries. Performance indicators - the UK, Austria, Romania have such indicators, while other countries (usually) do not have them. Citizens satisfaction - except for the UK, where the Government requires government departments to measure public satisfaction with their digital services and with other services overseen by government departments that may be provided by many organisations, countries do not regularly monitor or citizen satisfaction. 


\section{Concluding Remarks}

There are elements of effectiveness, efficiency, economy, and ethics of legislation present in countries, but they are not systemic in the eyes of system theory. Many times, even the most important element of systems - feedback or ex-post assessment, made in the realtime and place dimension - is not present. The most important national goals are usually (in the de facto meaning, with seriousness needed when dealing with public interest) not coordinated between ministries. The same stands for the Balkan region. ${ }^{10}$ This result contradicts within the previous section mentioned OECD documents. Countries need to strengthen the inter-agency collaboration, systemic assessment of the effectiveness of general decisions in the real-time dimension, they need to check the relevancy of agency's reasons for a draft bill, there should be some performance indicators and/or and possibilities to measure citizen satisfaction. In our time off information technology, such as online feedbacks cannot represent any technical difficulties. They are probably present more in political and other reasons. The key challenge for all CoGs will be a step from reporting on basic results to coordinating, monitoring and analysing outcomes of the government's work vis-à-vis the latter's short, middle and longer-term priorities in policy development and implementation. Changes in the environment will otherwise go their own way.

\section{References}

Alessandro, M., Lafuente, M., \& Santiso, C. (2013). The Role of the Center of Government: A Literature Review. Inter-American Development Bank.

Aristotle. (1992). Eudemian Ethics Books I, II, and VIII (M. Woods, Trans.). Oxford: Clarendon Press.

Aristotle. (1998). Politics (C. D. C. Reeve, Trans.). Indianapolis: Hackett Publishing Company.

Aristotle. (2004). Nicomachean Ethics (R. Crisp, Ed.). Cambridge: Cambridge University Press.

Davies, A. (2014). Centre Stage: Driving Better PoliciesFrom the Centre of Government, GOV/PGC/MPM(2014)3. Retrieved from http://www.oecd.org/officialdocuments/publicdisplaydocumentpdf $/$ cote $=$ gov $/ \mathrm{pgc} / \mathrm{mpm}(2014) 3 \&$ doclanguage $=$ en .

Douglas, M. (1986). How Institutions Think. Syracuse, N.Y.: Syracuse University Press. Einstein, A. (2007). The World As I See It. Minneapolis: Filiquarian Publishing, LLC. Fukuyama, F. (2014). Political Order and Political Decay: From the Industrial Revolution to the Globalization of Democracy. London: Farrar, Straus and Giroux. Hayek, F. A. (1998). Law, Legislation and Liberty: A New Statement of the Liberal Principles of Justice and Political Economy. Routledge.

\footnotetext{
${ }^{10}$ The primary challenges relate to the actual implementation of the functions that require well-developed capacities and good inter-institutional co-operation. One example of limited functioning concerns the coordination of policy content, where the function is partly established in Bosnia and Herzegovina, not clearly established in Serbia, and not fully functional in the remaining four Western Balkans governments [Kosovo, Montenegro, Albania and North Macedonia] (Vági, \& Kasemets, 2017).
} 
Hayek, Friedrich August. (2006). The Road to Serfdom. London; New York: Routledge. Hume, D. (2009). A Treatise of Human Nature. Auckland: The Floating Press.

Huntington, S. P. (1968). Political order in changing societies. New Haven and London: Yale University Press.

OECD. (2012). Slovenia: Towards a Strategic and Efficient State. Retrieved from http:// www.oecd-ilibrary.org/content/book/9789264173262-en.

OECD. (2015). Delivering from the Centre: Strengthening the role of the centre of government in driving priority strategies. Retrieved from https://www.oecd.org/gov/cog2015-delivering-priority-strategies.pdf.

OECD. (2017a). Government at a Glance 2017. Retrieved from http://dx.doi.org/10.1787/ gov_glance-2017-en.

OECD. (2017b). OECD Survey on Planning and Co-ordinating the Implementation of the SDGs: First results and key issues. Retrieved from https://www.oecd.org/gov/cob-sdgsurvey-overview-of-results.pdf.

Tax-Fin-Lex. (2019). Zakonodajni supervizor. Retrieved from https://www.tax-fin-lex.si/ Supervizor/VeljavniPredpisi.

Vági, P., \& Kasemets, K. (2017). Functioning of the Centres of Government in the Western Balkans, SIGMA Papers, No. 53. Retrieved from http://dx.doi.org/10.1787/2bad1e9c-en. Waldron, J. (2011). The Rule of Law and the Importance of Procedure. In J. E. Fleming (Ed.), Getting to the Rule of Law (pp. 3-31). New York and London: NYU Press.

Zimbardo, P. G. (2008). The Lucifer Effect: Understanding How Good People Turn Evil. New York: Random House Trade Paperbacks. 